\title{
䤃素抗体法による下垂体腺腫の免疫組織化学的観察
}

一Hyperprolactinemia 老伴う症例についてー

$$
\begin{aligned}
& \text { 寺本 明·松谷 雅生・平川 公義 } \\
& \text { 佐野 圭司·長村 義之*·渡辺 慶一* }
\end{aligned}
$$

\section{Immunohistochemical Observations of the Pituitary Adenomas with the Use of Enzyme Labeled Antibody Method}

-On the Cases with Hyperprolactinemia-

\author{
Akira Teramoto, Masao Matsutani, Kimiyoshi Hirakawa, \\ Keiji Sano, R. Yoshiyuki Osamura* and Kenghi Watanabe* \\ Department of Neurosurgery, University of Tokyo \\ * Department of Pathology, Tokai University
}

\begin{abstract}
Summary
Fifteen pituitary adenomas with hyperprolactinemia obtained at surgery were studied by an indirect immunoperoxidase technique for the demonstration of prolactin. (Anti-human prolactin was supplied by NIAMDD.) The immunoreactive prolactin was revealed in the cytoplasm of the tumor cells in 13 cases, which were classified into two types according to the population of prolactin cells and the intracytoplasmic localization of immunoreactive prolactin.

Type I-B cases-

The adenomas of this type consisted of numerous prolactin cells, which accounted for more than $90 \%$ of the tumor cells. These were strongly suggested to be the primary prolactin producing adenomas. Immunoreactive prolactin was characteristically found in the form of 'Nebenkern' in the cytoplasm of these adenoma cells, while it distributed evenly throughout the cytoplasm in normal prolactin cells. This finding suggested discrepancy of the hormone syntheses between normal and neoplastic prolactin cells. Clinically, serum prolactin levels were over $1,000 \mathrm{ng} / \mathrm{m} l$, and the tumor sizes were variable from intrasellar types to larger ones showing remarkable suprasellar extensions.

Type $I I-5$ cases-

The proportion of prolactin cells was only $10 \sim 30 \%$ of the tumor cells, which also contained growth hormone and/ or lutcinizing hormone in two cases. These adenomas, consisting of prolactin cells and some other cell types, might be considered to show the 'chimera' like proliferation. In contrast with Type I, intracytoplasmic immunoreactive prolactin was detected unevenly in each prolactin cells. Clinically, serum prolactin levels were about $100 \mathrm{ng} / \mathrm{m} l$, and all the tumors of this type showed moderate or marked suprasellar extensions. From this viewpoint, the interruption of prolactin inhibiting factor (PIF) might play some role to activate prolactin cells of these adenomas.

Since the immunohistochemical findings well reflected the serum prolactin levels in most cases, it might be considered that the origin of hyperprolactinemia can be attributed to the tumor itself.
\end{abstract}

Key words: pituitary adenoma, hyperprolactinemia, prolactin, enzyme labeled antibody method, immunohistochemistry

\section{東京大学脳神経外科}

*東海大学病理

〔連絡先： $\overline{\mathbf{T}} 113$ 東京都文京区本郷 7-3-1，東京大学脳神経外科，寺本 明]

1978年 2 月 16 日 受稿 


\section{Iはじめに}

近年, hyperprolactinemia 老伴ら下垂体腺腫がかなり 高頻度に坏告されており，いわ妕る chromophobe adenoma においては，その1/3以上がこの範疇に属するむ のと考えられている ${ }^{22)}$ ．それに伴い，血中 prolactin (PRL) 值測定の有用性が，診断，治療，予後の各面から 重要視され，数多くの研究がなされている375/2151202211.

一方，下垂体腙腫に扝ける hyperprolactinemia $の$ 病 態に関しては，従来一次的な腫湯分汹による場合，招上 び視床下部障害に伴ら PIF (prolactin inhibiting factor) 遮断による場合とが考えられていた。 また，後者におい ては，PRL 在分泌する主体加腫場自体加，残存下垂体 組織か，また注方の両者か上いら問題が存在する，しか し，このよらな各病態を臨例関して若察した報告は きわめて少なく，通常，PRL分泌腫瘍とのみ称している 場合が多い

我々は，hyperprolactinemia を呈した下垂体腺腫の症 例について，酵素抗体法による，腫瘍内 immuno-reactive PRLの免疫組織化学的観察を行い, 臨床像と比較検 討し，その病態関して若干の知見を得たので報告す る.

\section{II 対 象}

東京大学腷神経外科において，1972年 6 月から，1977 年 9 月までに手術を施行した下垂体腺腫は84例であり， その21例 $(25 \%) に$ hyperprolactinemia (basal level 30 $\mathrm{ng} / \mathrm{ml}$ 以上）を認めた。 なお Forbes-Albright 症候群は 4 例であった，以上の症例中，手術時摘出した材料が十 分な腫瘍組織を含んでおり，しかも保存性の良好なもの

Table 1 Summary of clinical data in reported 15 cases*

\begin{tabular}{|c|c|c|c|c|c|c|}
\hline No. & Subject & Age & Sex & $\begin{array}{c}\text { Size of sella } \\
\text { mm. }\end{array}$ & $\begin{array}{c}\text { Suprasellar } \\
\text { mass }\end{array}$ & $\begin{array}{c}\text { SerLm PRL } \\
\mathrm{ng} m \ell\end{array}$ \\
\hline 1 & $5 . k$ & 26 & $F$ & $16 \times 13$ & $M$ & 113 \\
\hline 2 & K.S. & 40 & $F$ & $14 \times 9$ & $\mathbf{L}$ & 135 \\
\hline 3 & T.F. & 26 & $\mathrm{~F}$ & $18 \times 13$ & $s$ & 5600 \\
\hline 4 & BN. & 65 & $F$ & $19 \times 14$ & $\mathbf{L}$ & $>1000$ \\
\hline 5 & N.K. & 42 & $M$ & $21 \times 16$ & $M$ & $>1300$ \\
\hline 6 & S. Y & 36 & $M$ & $21 \times 21$ & $M$ & 5980 \\
\hline 7 & $K W$. & 39 & $M$ & $19 \times 15$ & - & 1475 \\
\hline 8 & N. K. & 45 & $M$ & $18 \times 14$ & $M$ & 1183 \\
\hline 9 & F.N. & 24 & $\mathrm{~F}$ & $18 \times 11$ & $M$ & 100 \\
\hline 10 & K.R & 27 & $M$ & $25 \times 18$ & L & 8240 \\
\hline 11 & $T, E$ & 34 & $\mathrm{~F}$ & $22 \times 15$ & $M$ & 62 \\
\hline 12 & $Y . T$ & 22 & $F$ & $20 \times 14$ & 5 & 2000 \\
\hline 13 & M.K & 37 & $F$ & $12 \times 11$ & L & 84 \\
\hline 14 & N.N & 51 & $M$ & $32 \times 17$ & $M$ & 13800 \\
\hline 15 & N.M & 25 & $\mathrm{~F}$ & $18 \times 11$ & - & 763 \\
\hline
\end{tabular}

15例を本研究の対象とした（Table 1).

症例俚，22６5才までの男子6 例, 女子9例である。

腫瘍は，intrasellar type から著明な suprasellar extension を示すむのまでを含み，血中 PRL 值は $62 \mathrm{ng} / \mathrm{m} l$ から ら $13,800 \mathrm{ng} / \mathrm{m} l$ に及んた。. 従来の組織学的診断汁全例 chromophobe adenoma である.

\section{III 方法}

Nakane に上る酳素抗体法間接法を用( ${ }^{8) 11}$ ，PRL， growth hormone $(\mathrm{GH})$, luteinizing hormone $(\mathrm{LH}) \mathrm{K}$ 関 し，免疫組織化学的染色学行った．以下，PRLに例をと る(Fig. 1).10\%ホルマリンまたは Bouin 固定後, パ ラフィン包埋された盾瘍組織の切片を作製し，脱パラフ インを行 5。一次抗体として抗ヒトPRLウサギ血清 (NIAMDD 提供)を, 二次抗体として peroxidaseを ベルした抗「ウサギ $\gamma$ グロブリン」ヒッジ血清を作用さ せた㣪，3.3'-diaminobenzidine と $\mathrm{H}_{2} \mathrm{O}_{2}$ による発色反 态 (Graham \& Karnovsky $y^{4}$ ) 用いた。

な拉，Control test としては一次抗体を正常ウサギ血 清で置換して上記操作を行い，非特異的染色，才なわち background staining を検討した。

腫瘍切片の染色時, 剖検により得られた正常下垂体組 織をも同時に染色を行い，一次抗体の力価，特異性を確 認するとともに，全体の操作を通じてこの technical errorの指標とした.

最後に, counter staining として methyl green による 核染色を施し，脱水，封入した.

\section{IV 結 果}

Immuno-reactive PRL 法，15例中13例に証明され，主 として腫韵構成細胞における PRL 細胞の占める割合に

Pieces of tumor tissue were fixed in $10 \%$ formalin or Bouin's solution and embedded in paraffin.

$$
\downarrow
$$

Deparaffinize and hydrate.

$\downarrow *$

Apply rabbit anti-human prolactin (NIAMDD). Control : normal rabbit serum. $\downarrow *$

Apply peroxidase-labeled sheep anti-rabbit $\gamma$-globulin. $\downarrow *$

Incubate in 3.3'-Diaminobenzidine $+\mathrm{H}_{2} \mathrm{O}_{2}$. $\downarrow *$

Dehydrate and mount.

※ Wash in PBS.

Fig. 1 Indirect peroxidase-labeled antibody method (by P. K. Nakane) 
上り症例は大きく 2 型に分類されるとともに，細胞質内 PRL分布様式にむ若干の相異が認めら扎た（Table 2).

[第 I 型] 8 例 (Fig. 2，3)

PRL 紐胞が腫場構成細胞の $90 \%$ 以上を占める.腫瘍細 胞内 immuno-reactive PRL 江核に接して，核よりやや小

Table 2 Summary of immunohistochemical and morphologic findings

\begin{tabular}{|c|c|c|c|c|c|c|}
\hline & No. & Subject & $\begin{array}{l}\text { Immur } \\
\text { PRL }\end{array}$ & $\begin{array}{c}\text { ho-re } \\
\text { GH }\end{array}$ & $\begin{array}{l}\text { active } \\
\text { LH }\end{array}$ & Architecture \\
\hline \multirow{8}{*}{ Type 1} & 5 & N.K. & H & - & - & Diffuse \\
\hline & 6 & S.Y. & H & - & - & Diffuse \\
\hline & 7 & K.W. & H & - & - & Diffuse \\
\hline & 8 & N.K. & H & - & - & Diffuse \\
\hline & 10 & K.R. & H & - & - & Sinusoidal \\
\hline & 12 & Y.T. & H+ & - & - & Diffuse \\
\hline & 14 & N.N. & H+ & - & - & Diffuse \\
\hline & 15 & N.M. & H+ & - & - & Diffuse \\
\hline \multirow{5}{*}{ Type I } & 1 & S.K. & + & - & - & Sinusaidal \\
\hline & 2 & K.S. & + & + & - & Sinusoidal \\
\hline & 9 & F.N. & + & - & - & Diffuse \\
\hline & 11 & T.E. & + & + & + & Sinusordal \\
\hline & 13 & M.K. & + & - & - & Sinusoidal \\
\hline \multirow{2}{*}{ Negative } & 3 & T.F. & - & - & - & Diffuse \\
\hline & 4 & B. N & - & - & - & Diffuse \\
\hline
\end{tabular}
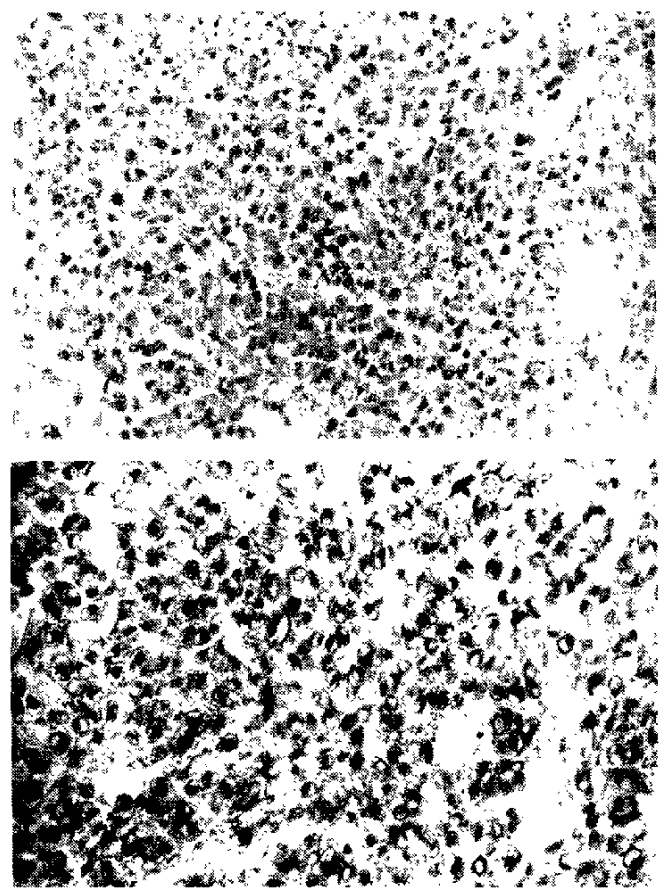

Fig. 2 Micrographs of type I. Top: Case 14 (fixed in 10 per cent neutral formalin). Bottom: Case 15 (fixed in Bouin's solution). The adenomas consist of numerous PRI cells, (immunoperoxidase staining for PRL $\times$ approx 400 )
型の塊状をなして存在しておる、この分布様式は第【 型 のすバてのPRL 細胞に共通した所見である。しばしば 核は偏在し，その対側の細胞質の大部分に，いわゆる “Nebenkern” 状の immuno-reactive PRL が証明され る.

一方，GH および LH に関しては全例 negativeであっ た.

細胞構築は一例老除いてすべて diffuse type を示し t.

\section{[第 II 型] 5 例 (Fig. 4，5)}

PRL 細胞は腫瘍構成細胞の一部であり， $10 \sim 30 \%$ 程 度である，腫瘍細胞内 immuno-reactive PRL の分布注， 基本的には前述した第 I 型と同様 “Nebenkern” 状に証 明される。しかし，immuno-reactive PRLは量的敒第 I 型がほぼ均一であるのに反し，第几型では比較的不揃い であって，きわめてわずかしか証明されない細胞から，

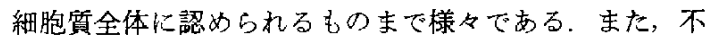
規則な cup-shape を示す PRL 細胞む散見される

一方, GH positive 1 例, GH およびLH がともに positive 1 例が媤められた.

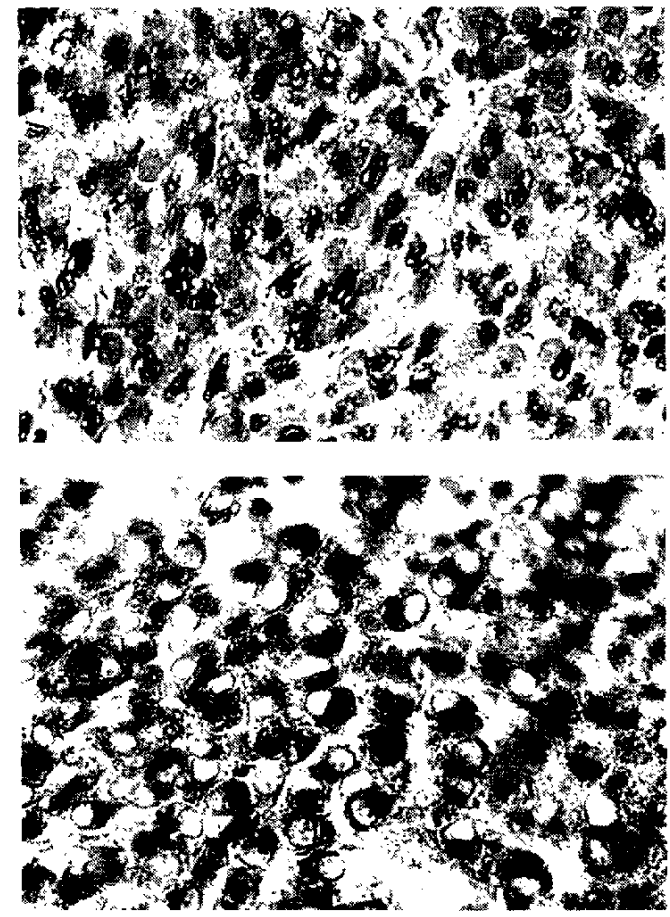

Fig. 3 Same cases as in Fig. 2. Immunoreactive PRL is evident in the form of 'Nebenkern' in the cytoplasm of almost all adenoma cells. (immunoperoxidase staining for PRL $\times$ approx 1,000 ) 


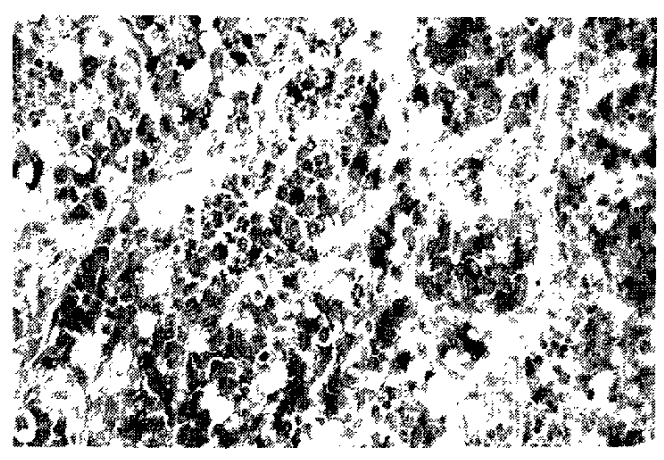

Fig. 4 Micrograph of type II. Case 11. PRI. cells are seen sparsely. (immunoperoxidase staining for PRL $\times$ approx 400)

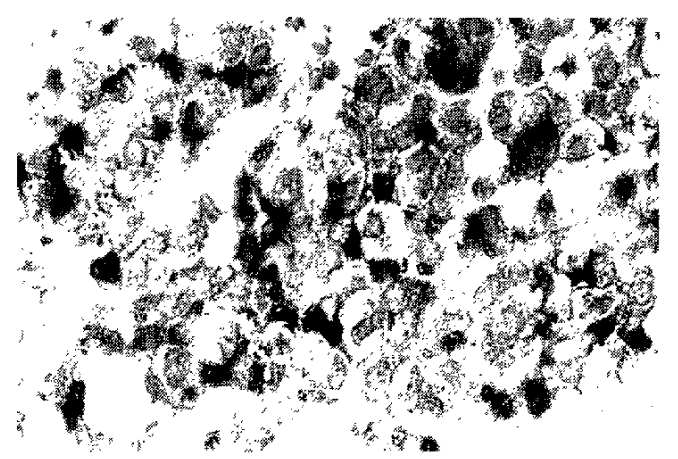

Fig. 5 Same cases as in Fig. 4. Immunoreactive PRL is detected unevenly in the cytoplasm of each PRL cells. (immunoperoxidase staining for PRL $\times$ approx 1,000 )

細胞構築は，5 例中 4 例が sinusoidal type であった。 Immuno-reactive PRLの証明されない症例法 2 例であ り，GH 执よび LH に関しても negativeであった。

\section{$\mathrm{V}$ 考 察}

酳素抗体法は，1966年，Nakane ら ${ }^{10111}$ によ開発さ れて以来, 免疫組織化学の分野に㧍い下着実に重要な役 割を荷ってきている。そして，酵素抗体法を用いた間脑 下垂体系に関字研究も次第にその数老増してはいるも

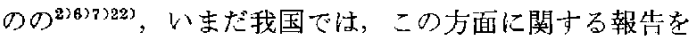
散見する程度にすぎない。

そこで，まず酵素抗体法を用いて，正常下烡体組織に おけるPRL 細胞の形態学的観察を行い，腫瘍組織に拉 けるをれとの相異在求めた（Fig．6，7）.

正常下垂体前葉には，現在 5 種類のホルモン産生細胞

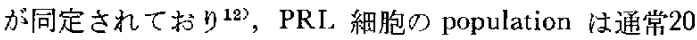
～30\%とされ，部位に上り多少その密度を異にするもの

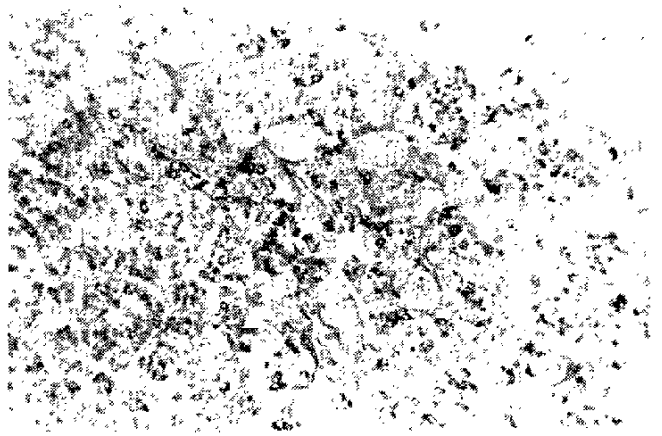

Fig. 6 Normal anterior pituitary gland. The population of $\mathrm{PRL}$ cells is estimated at $20 \sim 30 \%$. (immunoperoxidase staining for PRL $x$ approx 200)

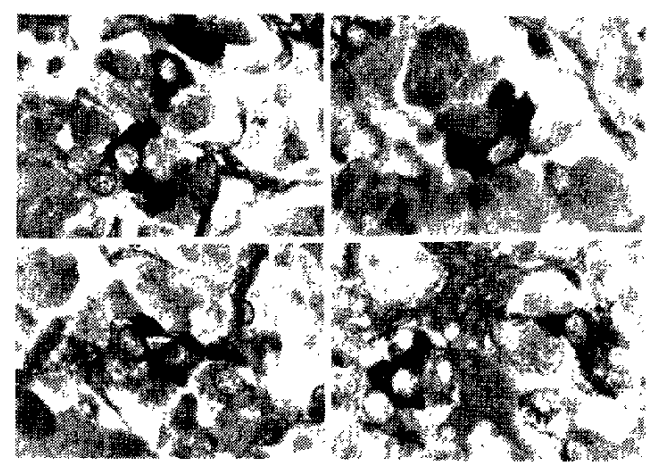

Fig. 7 Normal antcrior pituitary gland. PRL cells are frequently cup-shaped. (immunoperoxidase staining for PRL $\times$ approx 1,000 )

の，GH 細胞についで大きな割合を占める ${ }^{13)}$. 正常PRL 細胞は多くの場合，cup-shape をなしており，小型の円 形細胞を包含するような形態で存在している。 Nakane によるラット下垂体の観察で， PRL 細胞はやはり同 様り形態を示しており，LH 細胞をとりまいていると報 告さ机ている ${ }^{12)}$ ． 細胞内 immuno-rcactive PRL は細胞 質全体にほぼ均一に顆粒状に証明される。

一方，腫瘍組織，特に第 1 型に打汀る PRL 細胞はそ の population が90\%以上であり, 細胞形態は cup-shape を示するのはなく， oval polygonal type が大勢を占め る. 細胞内 immuno-reactive PRL 分布はきわめて特徴 的であり，核に接して核よりやや小さい隗状に証明さ れ，腫凘細胞すべてに共通寸石所見である。 Immunoreactive PRL の集族であるこの小鬼の様態は，ホルマy ン固定例の場合やや蜂单状となり，Bouin 固定例の場合 顆粒状となる㑯向がみられるむのの，その細胞質内局在 


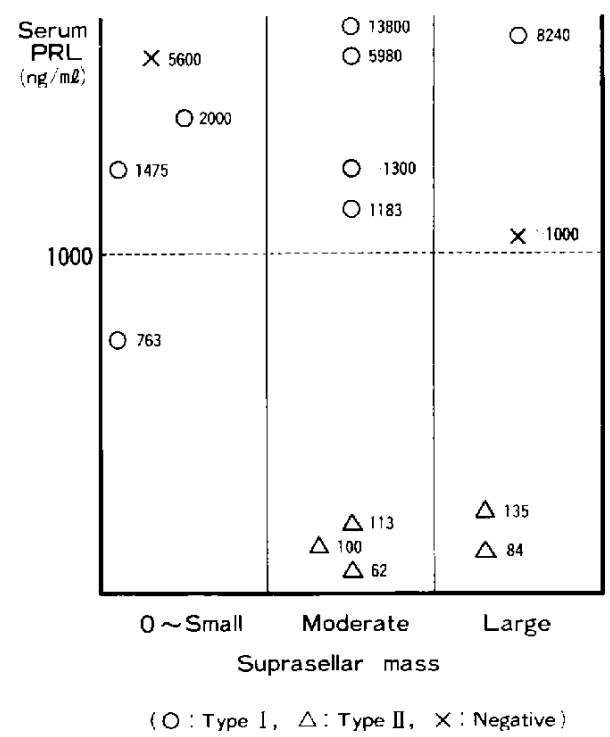

Fig. 8 Correlation between immunohistochemical findings, serum PRL and suprasellar mass.

には差異を認めなかった。一般に，醉素抗体法に扔ける 下垂体組織の固定としてはBouin 固定が賞用されるが, 同一症例に対するホルマリン固定とBouin固定とを比較 すると，後者の方がょり fine に immuno-reactive PRL の局在を表現寸る傎占がみられる。

以上のごとく正常 PRL 細胞と腫瘍における PRL 緗胞 とは, 形態学的相異に加光て, 細胞質内 immuno-reactive PRL の局在を異にすることから，両者におけるPRL 分 泌機構の差異を示唆するむのと考学られる，従来, functioning adenoma の電子顕微鏡的観察に扔いて，木ルモ ンの局在は直接的には分泌顆粒に，閒接的には endoplasmic reticulum や Golgi apparatus などに求めら机て いた ${ }^{16)}$. 今回光学顕微鏡 level で観察された, この "Nebenkern" の fine structure K開して免疫電顕の手法 を用いた研究が今後の課題である。

つぎに，PRL 分泌腫瘍における免疫組織化学的観察 の結果を臨床像との関連で検討した〈Fig. 8).

第 I 型は763 $\mathrm{ng} / \mathrm{m} l \sigma 1$ 例老除きすべて血中 PRL 值 $1,000 \mathrm{ng} / \mathrm{m} l$ 以上の症例であり，腄瘍組織に括けるPRL 細胞の頻度を反映していると考えられる。腫場の発育型 は, intrasellar type 加ら藷明な suprasellar extension を示すものまでが存在する．TRH に対する血中 PRL 值の反応はほ上んど認められなかった。なお，男性例が 全例第 I 型に属していることは與味哚く, 男性に打ける PRLの内分泌学的意義との関連を示唆する.

第吕型に関しては，す心゙て血中 PRL 值か $100 \mathrm{ng} / \mathrm{m} l$
前後の症例であり, 中等度以上の supra-sellar extension 在伴っていた，また，TRH に対する血中 PRL值の変動 は無反店ないし低反忘であった。

以上の結果から，第I 型に属する腫瘍は，元来 PRL を分泌する腫瘍 (primary PRL producing tumor) である ことが強く示唆される.第而型に関しては，いくつか の病態が考えられる。その1つは腫瘍が中等度以上の suprasellar extension交していることから，視床下部な いし下垂体蒸障害し, prolactin inhibiting factor (PI F)を遮断することにより腫瘍もしくは残存下垂体の PR L 細胞を activate 寸る場合である，第 2 には，第II型の 一部に GH および LH が positive であることから，PRL 細胞含含複数の cell type が，い加ば "chimera" 的に 增殖していることが考えられる。高 PRL 血症の責任病 米を考える時, 正常下垂体組織の PRL 分必能力が問題 となる。各種薬用による刺激効果 ${ }^{1}$, stalk section ${ }^{19)}$, craniopharyngioma 等ホルモン非分泌腫瘍による物理的 PIF 遮断效果纪基づく高PRL 血症仙通常 $200 \mathrm{ng} / \mathrm{ml}$ 以 内であり，500 ng/ml 以上となることはきわめて稀であ $ろ^{17118)}$.中えに，二机以上の高PRL 血症は下垂体組織 の分泌能力を越えており，腫瘍の autonomic secretionと 考えるのが妥当であるう.Immunohistochemical stainに て証明されたPRL 細胞の頻度に加えて, 前述した理由 加らも第I型に抬ける高 PRL 血症の責任病巣は腫瘍に 求められよう。一方，第而型に関しては血中 PRL 值の みでは判定不可能であるが, immunohistochemical stain にて PRL 細胞が証明されることから，少なくとも腫瘍 も責任病宩の役割を荷っているといえよう。

属瘍組織内 immuno-reactive PRL $の$ negative 例は 2 例でありいずれも古い症例に属し，その antigenicityの 保存性が問題となる. Immunohistochemical stain にお いては常に固定による antigenicity の跬失が重要な問題 てあるが, 時閒の経過とともに変性の要素も考虑しなけ ればならない。をれゆえ，positive 例に関してはその形 態学的観察をなしらるが, negative 例については対象と する抗原が存在しないといらことと必ずしも等価でない 場合があるため，その意義付けはしばしば困難である。 ただし，現在までの検索では少なくとも GHやPRL 等 peptide hormone に関しては，数年前のホルマリン固定 パラフィンブロックの材料でも比較的良好な結果が得ら れることが知られている゙。

\section{VI 結 論}

Hyperprolactinemia を呈した下垂体腫瘍15例に関し， 䤃素抗体法を用いて免疫組織化学的観察を行い, 臨床像 


\section{と比較検討した。}

1. Immuno-reactive PRL陽性例は13例であり, PRL の分布形態により大きく 2 型に分類された。また，腫瘍 における PRLの細胞内分布はいわゆる"Nebenkern"と して存在し，正常 PRL 細胞のそれと異なっていた.

2. 第 I 型は PRL 細胞ほほ一色の密な增殖形態を示 し, primary PRL producing tumor であることを強く示 唆する. 臨床的には血中 PRL 值 $1,000 \mathrm{ng} / \mathrm{m} l$ 以上を呈 しそその発育型には特に傾向を認めない。

3. 第型は PRL 細胞の䫁度が低く，その病態に関 して若干の考察を加えた。臨床的には血中 PRL 值 100 $\mathrm{ng} / \mathrm{m} l$ 前後であり，中等度以上の supra-sellar extension を示した.

4. 高 PRL 血症の責任病巣は第 I 型では腫瘍に求め

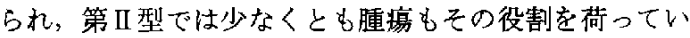
ると考えられる。

本論文の要旨は，第36回日本腷神释外科学会総会 (1977 年，大阪）に括いて器表した。

\section{文献}

1) Clemens, J. A., Smalstig, E. B. \& Sawyer, B. D.: Antipsychotic drugs stimulate prolactin release. Psychopharmacologia (Berl.) 40: 123-127, 1974

2) Corenblum, K., Slrek, A. M. T., Horvath, E., et al.: Human mixed somatotrophic and lactotrophic pituitary adenoma. $J$ Clin Endocrinol Metab 42: 857-863, 1976

3) Frank, S., Jacob, H. S. \& NabrRo, J. D. N.: Proceedings: Studies of prolactin secretion in pituitary disease. $J$ Endoclinol 67: 55, 1975

4) Graham, R. C. \& Karnovsky, M. J.: The early stages of absorption of injected horse-radish peroxidase in the proximal tubules of mouse kidney. Ultrastructual cytochemistry by a new technique. J Histochem Cytochem 14: 291-302, 1966

5) Hwang, P., Guyda, H. \& Friesen, H.: A radioimmunoassay for human prolactin. Proc Natl Acad Sci USA 68: 1902-1906, 1971

6) Kovacs, K., Horvath, E., Corendlum, B., et al: Pituitary chromophobe adenomas consisting of prolactin cells. Virchows Arch [Pathol Anat] 366: 113-123, 1975

7) Kovacs, K., Corenblum, B., Sirek, A. M. T. et al: Localization of prolactin in chromophobe pituitary adenomas: Study of human necropsy material by immunoperoxidase technique. $J$ Clin Pathol 29: 250-258, 1976
8) 瓦井康之 \& NAKANE, P.K.: 䣲素抗体法一最近 の方法論的進步を中心として一，蛋白質・核酸 - 酵菜 $20: 1007-1013,1975$

9) Malarkey, W. B. \& Johnson, J. C.: Pituitary tumors and hyperprolactinemia. Arch Intern Med 136: 40-44, 1976

10) Nakane, P. K. \& Pierce, G. B.: Enzyme-labeled antibodies: Preparation and application for the localization of antigens. $J$ Histochem Cytochem 14: 929-931, 1966

11) NaKane, P. K.: Simultaneous localization of multiple tissue antigens using the peroxidase-labeled antibody method. A study on pituitary gland of the rat. $J$ Histochem Cytochem $16 ; 557-560$, 1968

12) Nakane, P. K.: Classification of anterior pituitary cell types with immunoenzyme histochemistry. $J$ Histochem Cytochem 18: 9-20, 1970

13) Nakane, P. K.: Recent progress in the peroxidase-labeled antibody method. Ann NY Acad Sci 254: 203-211, 1975

14）長村義之，渡辺慶一：醭素抗体法一原理より 内分泌応用までー。ホルモンと臨床 $24: 1074-$ 1087,1976

15) Perez-Lopez, F. R.: Hypothalamic pituitary disorders expressed by galactorrhea. A dynamic evaluation. Obstet Gynecol 46: 621-626, 1975

16) Robert, F. \& HARdy, J.: Prolactin-Secreting adenomas. A light and electron microscopical study. Arch Pathol 99: 625-633, 1975

17) Tolis, G., Goldstein, M. \& Friesen, H. G.: Functional evaluation of prolactin secretion in patients with hypothalamic-pituitary disorders. $J$ Clin Invest 52: 783-788, 1973

18) Tolis, G., Somma, M., Van Campenhout, J. \& Friesen, H. G.: Prolactin secretion in sixty-five patients with galactorrhea. Am $J$ Obstet Gynecol 118: 91-101, 1974

19) Turkington, R. W., Underwood, L. E. \& VAN WYK, J. J.: Elevated serum prolactin levels after pituitary-stalk section in man. $N$ Eng $J$ Med 285: 707-710, 1971

20) Turkington, R. W.: Secretion of prolactin by patients with pituitary and hypothalamic tumors. $J$ Clin Endocrinol Metab 34: 159-164, 1972

21) Yamaji, T., Shimamoto, K., Ishibashi, M., et al.: Effect of age and sex on circulating and pituitary prolactin levels in human. Acta Endocrinol 83: 711-719, 1976

22) Zimmerman, E. A., Defendini, R. \& Frantz, A. G. : Prolactin and growth hormone in patients with pituitary adenomas. A correlative study of hormone in tumor and plasma by immunoperoxidase technique and radioimmunoassay. I Clin Endoclin Metab 38: 577-584, 1974 